Artigo original

Hegemonia - Revista Eletrônica de Relações Internacionais do Centro Universitário Unieuro

ISSN: $1809-1261$

UNIEURO, Brasília, número 9, 2012, pp. 68-104.

Recebido em: 13/11/2011

Revisado em: 8/12/2011

Aprovado em: 19/12/2011

\title{
O Acordo Tripartite, Brasil, Turquia e Irã: novos rumos para a paz no Oriente Médio
}

CHAGAS, Bruno Rezende Santiago ${ }^{1}$

Resumo: O artigo aborda as relações entre o Brasil e os países do Oriente Médio, com ênfase na questão iraniana.

Palavras-chave: Brasil, Oriente Médio, Irã.

\section{Introdução}

Interpretar o sucedido nos entendimentos tripartite celebrados entre Brasil, Turquia e a República Islâmica do Irã, requer baixar a lupa sobre o terreno político, diplomático e geopolítico. Em realidade, estes três Estados buscaram não apenas cumprir demandas internacionais respeito ao programa nuclear iraniano. Buscaram agir pragmaticamente segundo seus interesses políticos e de negócios em

Pós Graduado em História Social e das Idéias, UnB. Especialista em Política e Governo pela Universidade Lusófona, Lisboa. Mestrando em Ciência Política da UNIEURO, DF. Professor universitário e da SEE/DF. 
Artigo original

Hegemonia - Revista Eletrônica de Relações Internacionais do Centro Universitário Unieuro

ISSN: $1809-1261$

UNIEURO, Brasília, número 9, 2012, pp. 68-104.

foco ${ }^{2}$. Mais uma vez, é preciso assentar o olhar sobre dois importantes ângulos definidos: o contexto internacional local, repousado sobre a firmeza nacionalista de Teerã, e os interesses nacionais destes dois Estados protagonistas, Brasil e Turquia.

Para tanto, o presente texto intenta deslindar estes dois ângulos apresentados acima, como também o papel da diplomacia brasileira no contexto conflitivo e interventivo do Oriente Médio. $O$ Brasil não representa uma aventura introdutória naquela região. Como pátria adotiva de milhões de árabes, sejam muçulmanos ou cristãos, a política brasileira é atenta quanto o desdobrar político que afeta a região. Para o caso, a questão nuclear iraniana promovida pelas potências ocidentais, afeta diretamente o mundo árabe, e por conseguinte, os interesses brasileiros na grande área. Ademais, que como se observará, a própria República Islâmica é território de relevo para a expansão econômica brasileira, que defende portas abertas como alavanca para o desenvolvimento do país. Neste quadro interpretativo, se buscará também notar se a diplomacia brasileira matizada nos recentes vôos autonomistas e de pragmatismo - está à altura de representar esta crível expansão econômica nacional.

As sanções dirigidas ao Irã pelo Conselho de Segurança das Nações Unidas, em 09 de junho de 2010 (Res. No 1929) foi um balde de água fria no trabalho conjunto dos três países (Brasil, Turquia e Irã). Mas não significa o insucesso da obra. A postura equânime e dialogal destes Estados, os referendou como atores fiáveis nas turbulentas relações do Oriente Médio. Entre o endurecimento movido por EUA e aliados europeus, que quase sempre tem enrijecido os avanços práticos, surge a atividade brasileira - e turca - focada na

Biato, Marcel. Por uma Nova Plataforma Produtiva Brasileira. Este diplomata brasileiro, defende o protagonismo do Brasil onde concretamente existam interesses políticos e econômicos, e que para tanto, é necessário uma nova geografia econômica e comercial no mundo. Disponível em: www.mre.gov.br/africaorientemedio/biato. 2010. 
Artigo original

Hegemonia - Revista Eletrônica de Relações Internacionais do Centro Universitário Unieuro

ISSN: $1809-1261$

UNIEURO, Brasília, número 9, 2012, pp. 68-104.

resolução franca dos problemas. Como disse a Embaixadora Maria Luísa Ribeiro, em entrevista recente

"... achamos que compartilhamos da percepção de que é necessário que o Irã possa esclarecer qualquer dúvida que haja sobre a natureza do seu programa (nuclear). Mas achamos que a maneira mais viável de conseguir esse objetivo é através do diálogo, da negociação e da obtenção da cooperação do Irã. Por isso é que penso que a proposta tripartite deverá ser revitalizada em breve..." ${ }^{\prime 3}$

O desenrolar dos acontecimentos por ocasião da imposição das mais duras sanções internacionais contra o Irã, ativou o Estado brasileiro. Numa exposição ao mundo, o Brasil revelou sua interessante diplomacia presidencial ${ }^{4}$, distinta e facultada à liderança pessoal exercida pelo Presidente Lula. A ação foi visada em duas frentes: garantir maior projeção internacional, empresariando possíveis acordos que propiciassem uma détente entre o Ocidente e o Irã; e assegurar os investimentos brasileiros bem como as atividades econômicas com o país persa.

O presente texto estudará estas duas frentes como o principal capítulo da marcha diplomática brasileira em relação ao Irã, que teve

Viotti, Maria Luísa Ribeiro. Entrevista concedida em 07 de março de 2010. Disponível em: www.ultimosegundo.ig.com/politica/brasil/cenario.

Maihold, Gunther. Demasiado Mundo: Lula, Brasil e Medio Oriente. In: www.realinstitutoelcano.org/portal/contenido. 
Artigo original

Hegemonia - Revista Eletrônica de Relações Internacionais do Centro Universitário Unieuro

ISSN: $1809-1261$

UNIEURO, Brasília, número 9, 2012, pp. 68-104.

um coroamento factual nos acordos tripartite de 2010. Pretende-se chegar a uma interpretação mais direta e histórica ante os sucessos protagonizados por Brasília e Ancara relativos à problemática nuclear iraniana. Como nota o escritor espanhol Pepe Escobar, o mundo ocidental vive uma psicose chamado "iranofobia" onde qualquer sinal emitido da República Islâmica é imediatamente tido como passos para o fabrico da bomba nuclear. Assim, se visa dar mais amplitude histórica e atual à opinião pública brasileira sobre o caso nuclear iraniano e situar a intervenção do Brasil como importante passo rumo ao entendimento multilateral.

Desta feita alguns pontos serão relevantes para aclarar a situação geopolítica e a atuação brasileira no marco tripartite:

> O quadro geopolítico regional e seus impactos na arena global, protagonizado em primeira mão pela questão nuclear iraniana;

> A solicitação norte-americana para a mediação brasileira e turca, assim como os motivos que levaram Washington a endereçar ao Brasil tal empreitada;

> Os reais motivos que levaram Brasília a adotar a diplomacia presidencial para o específico caso nuclear iraniano, em parceria com o governo turco de Erdogan;

> O que representa o Irã para a sociedade brasileira em geral, as potencialidades entre os dois países e o que se realiza no âmbito das relações bilaterais;

> A efetividade dos acordos tripartite, seus resultados e a imagem conferida ao Brasil no Irã e nos Estados fronteiriços árabes, imediatos ao país persa, para saber se o Brasil se consolida como um interlocutor fiável para as partes em conflito na região.

\section{Cenário regional: um Irã nuclear?}


Artigo original

Hegemonia - Revista Eletrônica de Relações Internacionais do Centro Universitário Unieuro

ISSN: 1809-1261

UNIEURO, Brasília, número 9, 2012, pp. 68-104.

O controvertido programa de capacitação nuclear iraniano para fins energéticos, não é novo e não está desvinculado com as políticas das grandes potências ocidentais. Sua origem remonta aos anos 1960, durante a monarquia, quando o Xá Reza Pahlevi e o Presidente Richard Nixon, assinaram acordos para a transferência de tecnologia nuclear ao país, em 1969. ${ }^{5}$ Importante salientar que nesta altura o Irã monárquico representava o principal pilar da influencia norteamericana em toda região do Golfo Pérsico. Seu exército, enorme e desproporcional para os tradicionais aliados como Arábia Saudita e Israel, contava com os mais modernos produtos da indústria bélica mundial. Tanto, que no conflito com o Iraque, as armas norteamericanas, novíssimas, foram empregadas contra o novo aliado de Bagdá.

Todavia a situação se altera drasticamente em 1979 com a Revolução Islâmica, de corte fundamentalista, liderada por Khomeini. Deve-se também salientar que o traço mais simbólico da revolução iraniana foi o fundamentalismo xiita, alçado ao poder de Estado, porém sua marca mais profunda era o acentuado nacionalismo das camadas médias e populares. Essa revolução religiosa, mesclada de nacionalismo, logrou espraiar-se por todo a nação persa com suas clássicas medidas "anti-imperialistas", como a nacionalização da indústria petrolífera, reforma agrária, controle público da economia e das finanças. Estas duras afirmações no campo dos negócios talvez foi o mais sentido pelos grupos transnacionais que atuavam no Irã a décadas, sejam norte-americanos, britânicos ou europeus.

No decurso dos anos 1980, o Irã foi paralisado em seus avanços - incluso o nuclear - pela devastadora guerra contra o Iraque de Saddam Hussein. Com o cessar fogo de 1988, o país passou literalmente a ser fustigado pelo Ocidente, devido a sua opção islâmica, e manutenção das políticas nacionalistas, que afetavam a 
Artigo original

Hegemonia - Revista Eletrônica de Relações Internacionais do Centro Universitário Unieuro

ISSN: $1809-1261$

UNIEURO, Brasília, número 9, 2012, pp. 68-104.

expansão das companhias ocidentais no Golfo. Às duas guerras movidas pelos EUA, Grã Bretanha e aliados da OTAN contra o Iraque, culminando na invasão de 2003, o Irã voltou à primeira cena das instabilidades e receios globais. A eleição do clérigo Mohamed Katamy em 2000, com sinais de liberalização do regime, não foram bem acolhidas pelas grandes potências. Por seu turno, continuava a passos largos o desenvolvimento da capacidade nuclear iraniana, mesmo este país colaborando com a AIEA. ${ }^{6} \mathrm{O}$ principal fornecedor tecnológico para o programa nuclear com finalidades civis de Teerã foi a Rússia, em sua nova fase expansiva internacional, sob a liderança do Presidente Vladimir Putin. ${ }^{7}$

Contudo, a eleição do ex-líder estudantil e prefeito de Teerã, o popular Mahmud Ahmadinejad em 2004, solidificou a tendência nacionalista do país. É precisamente neste contexto que deve ser entendida as pressões movidas pelas grandes potências ocidentais contra o Irã, através do regime de sansões aplicados contra este país. E também é neste contexto que deve ser analisado a presença de novos atores no caso nuclear iraniano, como Turquia, Rússia e mais especificamente Brasil. E sobretudo é nesta atmosfera política, tensionada pelas ameaças mútuas e demonstrações de força, que deve ser agregado o fator israelense.

\section{O fator Israel}

Agência Internacional de Energia Atômica. Relatório anual dos trabalhos realizados. Conferência Pública dos Técnicos da Agencia em Viena, Áustria. Disponível em: www.iaea.org/concil/2002. (em inglês)

Agência russa de notícias Ria Novosti. In: www.rianovosti.ru/sp. Las cabezas nucleares de Irán. 2011. Em espanhol. 
Artigo original

Hegemonia - Revista Eletrônica de Relações Internacionais do Centro Universitário Unieuro

ISSN: 1809-1261

UNIEURO, Brasília, número 9, 2012, pp. 68-104.

A principal força aliada do Ocidente - termo utilizado aqui em seu sentido geopolíitco, ou seja, EUA e parceiros da OTAN - no Médio Oriente é Israel. Particularmente para EUA, Grã Bretanha e Alemanha, a defesa de Israel é condição sine qua non na arquitetura política que estabelecem para toda a grande região do Levante. Apenas em dez anos três Estados do Oriente Médio tiveram suas capacidades militares estratégicas literalmente reduzidas pela ação de Israel coordenada pelos EUA: em 1981 quando o reator nuclear iraquiano de Osirak foi destruído pela aviação israelense, utilizando o espaço aéreo jordaniano e saudita graças à intermediação de Washington; em 1982-1985 quando Israel ataca o Líbano devastando o país e liquidando as forças palestinas e libanesas; e em 1988 ultimo ano da guerra Irã-Iraque quando sua aviação bombardeia (sem declaração de guerra) o importante reator nuclear de Natanz, no oeste iraniano.

Esta agressão sem motivos aparentes, jamais foi perdoada ou esquecida pelo regime iraniano, que a somou como mais um movimento "diabólico" perpetrado contra sua revolução. Data desta época a frase do Aiatolá Khomeini, que às vésperas de sua morte, proclama que a

"entidade sionista - Israel - deveria ser varrida do mapa a bem da nação árabe e muçulmana."

Não obstante a maioria absoluta da dirigência iraniana repetir univocamente a frase do Guia Supremo, a mídia ocidental atem-se obstinadamente aos discursos do presidente Ahmadinejad, "jurando varrer Israel do mapa", como se fosse algo extemporâneo para o regime islâmico de Teerã.

$\mathrm{Na}$ realidade, dentre as origens pioneiras das pressões contra a República Islâmica, e o regime de sansões internacionais, encontrase $o$ fator israelense. Segundo os analistas norte-americanos Kathleen e Bill Christison, do sítio de análise global Counter Punch, Israel é de longe o maior receptor de "ajuda em defesa e segurança" dos EUA no Médio Oriente. Os dois países firmaram um Memorando de Entendimento em agosto de 2007, onde Washington se 
Artigo original

Hegemonia - Revista Eletrônica de Relações Internacionais do Centro Universitário Unieuro

ISSN: $1809-1261$

UNIEURO, Brasília, número 9, 2012, pp. 68-104.

comprometera a repassar um efetivo de U\$ 30 bilhões para os próximos nove anos, pagos a início de cada ano fiscal ${ }^{8}$. A única imposição por parte de Washington constante no Memorando é que ao menos $74 \%$ desse valor seja invertido na compra de bens e serviços militares dos EUA. Nada mais apropriado para os bons negócios entre as ETNs do complexo industrial-militar norteamericano e o próprio governo, financiador e fiador da "ajuda".

Por informações desses mesmos pesquisadores o enviado da Casa Branca para as negociações palestino-israelenses, o ex-senador democrata George Mitchell, declarara em recente entrevista que

"... nada nos preocupa mais que a segurança de nossos amigos e aliados. A segurança de Israel é uma clausula pétrea para a diplomacia e a política dos EUA no Oriente Médio, e não prescindiremos de confrontar quaisquer obstáculos..."

Desde a ascensão ao poder do presidente Ahmadinejad, coincidentemente com a chegada ao poder em Israel de Ehud Olmert, que densas nuvens projetam-se sobre os dois países, com um toque inflamável da presença militar norte-americana na zona. Os EUA estão presentes, unilateralmente ou em parceria com a OTAN em todas as fronteiras com o Irã: a leste, no Afeganistão ocupado por mais de 100 mil efetivos militares; a oeste, no Iraque também ocupado, com mais de 50 mil soldados e mercenários estacionados a

Christison, Bill. Stop \$ 30 Billion Coalition. Universit of Albuquerque. In: www.counterpunch.org/christison. 2008

Op. Cit. p. 02. 
Artigo original

Hegemonia - Revista Eletrônica de Relações Internacionais do Centro Universitário Unieuro

ISSN: $1809-1261$

UNIEURO, Brasília, número 9, 2012, pp. 68-104.

escassos vinte quilômetros da divisa com a província árabe do Cuzistan; a noroeste com a fronteira turca, um membro pleno da OTAN; e ao sul margeando o Golfo, estão de prontidão naves da armada norte-americana do Indico com mísseis permanentemente apontados para as costas iranianas. Basicamente desde as guerras da Indochina, que os EUA não mobilizam tamanho arsenal contra um único país, em que formalmente não se encontram em estado de guerra. ${ }^{10}$

Como se pode observar no mapa abaixo, elaborado pelo analista espanhol Pepe Escobar, as bases militares norte-americanas, britânicas e da OTAN, enfileiram-se por todo entorno iraniano, e mais além, garantindo uma zona de pressão (e tensão) inigualável ao país persa. Distingue-se bases militares em sentido convencional, centros de operações aero-terrestres, centros de comando conjunto Estados árabes-OTAN, e aeródromos de logística intermodal. Estes últimos situando-se no litoral, particularmente do Golfo Pérsico. É digno de nota, a densidade de bases na região meridional iraniana, próximo a fronteira com o Kuwait, não por acaso nas principais áreas de extração petrolífera do Irã, e onde se encontra ainda o complexo petroquímico de Ahvaz, o maior do Golfo. No leste, junto à fronteira afegã, as bases dispõem-se a cobrir toda a extensão oriental do país, e segundo a chancelaria iraniana, é por onde entram clandestinamente as armas para grupos insurretos que agem a soldo de EUA e aliados.

Chossudovsky, Michel. La Geopolítica de los pipelines y gaseoductos. In: www.globalresearch.ca/chossudovsky/iran/pipelines. 2010. Neste ensaio do professor canadense, pode-se visualizar os mapas da presença militar estadunidense como um cerco estratégico sobre os recursos energéticos do país persa. 
Artigo original

Hegemonia - Revista Eletrônica de Relações Internacionais do Centro Universitário Unieuro

ISSN: $1809-1261$

UNIEURO, Brasília, número 9, 2012, pp. 68-104.

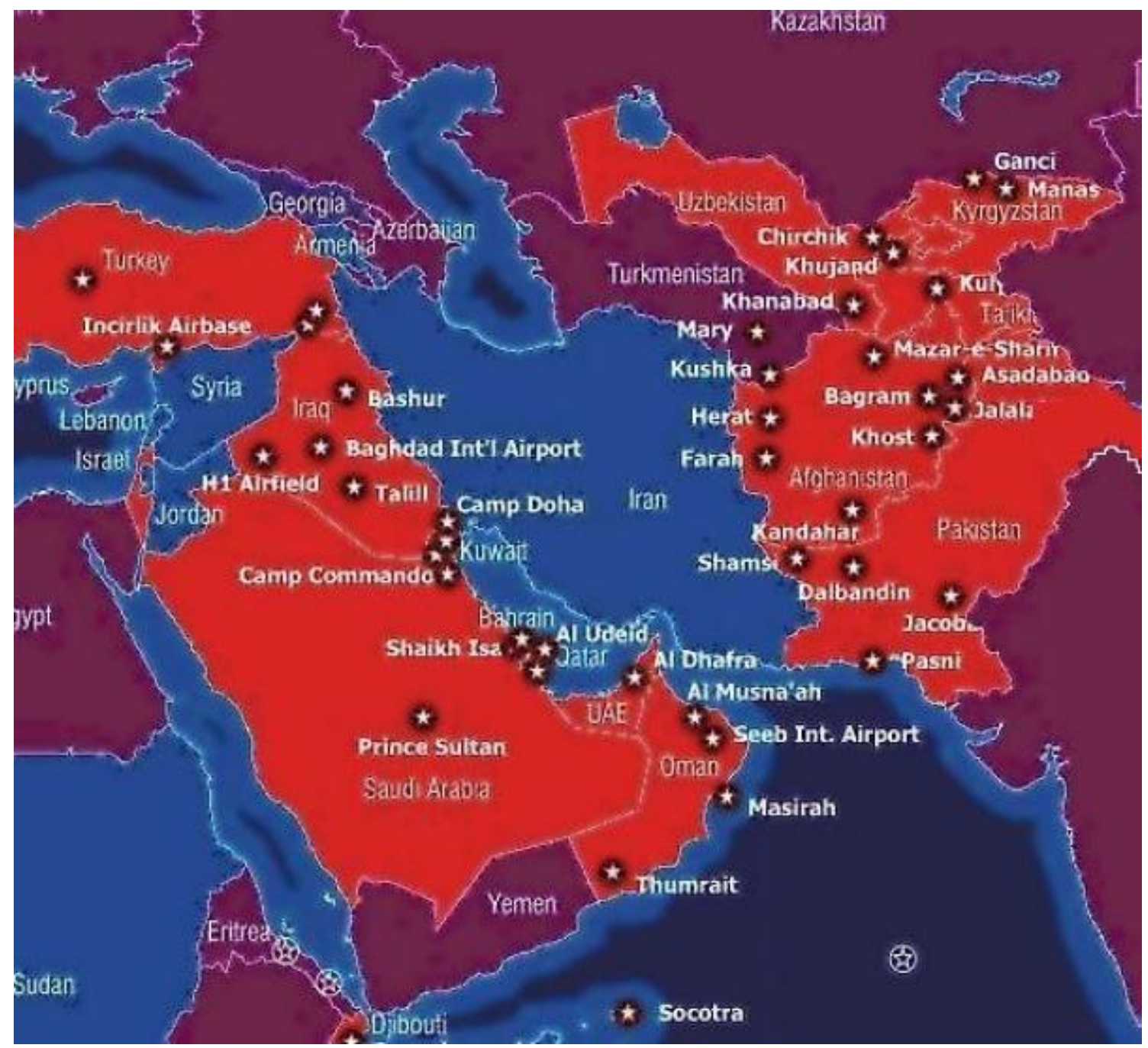

Bases, centros de operações militares, aeródromos logísticos e centros de comando da Aliança Atlântica no Médio Oriente. Pepe Escobar. ${ }^{11}$

Desde que os EUA pressionaram os Estados membros do Conselho de Cooperação do Golfo, formado pelos Emirados Árabes Unidos, Arábia Saudita, Bahrein, Kuwait, Omã e Qatar, o Irã se

Escobar, Pepe. A Pedregosa Estrada para Damasco. Disponível em: www.rededemocratica.pt/pepeescobar. 2011. 
Artigo original

Hegemonia - Revista Eletrônica de Relações Internacionais do Centro Universitário Unieuro

ISSN: 1809-1261

UNIEURO, Brasília, número 9, 2012, pp. 68-104.

reporta a uma situação conflitiva a seu redor. Por ocasião da Conferência em Doha, no Qatar, foi pronunciada a nota oficial em que esses referidos países temem pelo programa nuclear iraniano, algo inusitado até então. O professor da Universidade de Otawa, Michel Chossudovsky pondera as frenéticas reuniões, pontes aéreas e visitas entre a Secretária de Estado $\mathrm{H}$. Clinton, o Secretário de Defesa da época R. Gates e altos diplomatas com os monarcas e diplomatas árabes do Conselho de Cooperação, para lograr transformar o programa nuclear, e mesmo o regime iraniano, numa "ameaça" aos vizinhos. Israel igualmente aplaudiu a postura coletiva das teocracias árabes contra a República Islâmica, e através de seu novo premiê $B$. Netanyahu, incitou todos a tomarem posição unificada contra Teerã.

Portanto o contexto militarizado prenhe de ameaças e tensões ao redor do Irã está diretamente relacionado ao fato de Israel ser a única potência nuclear do Médio Oriente. Muito embora Tell Aviv não admita, ou mesmo permita inspeções internacionais, ou sequer subscreva entendimentos com a AIEA, todos os serviços de inteligência mundiais, especialistas e governos árabes ou muçulmanos afirmam serem críveis as possibilidades de Israel possuir ogivas atômicas. Até o presente momento as autoridade israelenses negam as denúncias, porém não admitem a existência de um Irã nuclearizado, seja para fins pacíficos ou muito menos para fins defensivos. A atuação dos lobbys israelenses na alta cúpula da política norte-americana, no Congresso, na mídia e na Casa Branca, fazem com que a engenharia geopolítica dos EUA - e por conseguinte aliados-parceiros da OTAN - com relação ao Irã seja de permanente ameaça, tons belicistas e, como evidenciam as disposições militares, cerco territorial.

O programa nuclear iraniano como ameaça imediata a Israel ou qualquer interesse norte-americano na região não é crível, isso, pelas divulgações da própria Inteligência dos EUA. ${ }^{12}$ Em fins de 2007,

McGovern, Ray. El Momento Oportuno para que Israel Bombardeie Irán?. Disponível em: Information Clearing House. In: www.clearinghouse.org.us/mcgovern/iran. 2010. 
Artigo original

Hegemonia - Revista Eletrônica de Relações Internacionais do Centro Universitário Unieuro

ISSN: $1809-1261$

UNIEURO, Brasília, número 9, 2012, pp. 68-104.

momento em que os tons de ataque ao Irã recrudesciam na administração Bush e no governo israelense, a comunidade de inteligência dos EUA torna público seu relatório sobre os avanços do programa nuclear iraniano. Textualmente afirmavam que:

"...Julgamos com muita confiança que no outono de 2003, Teerã interrompeu seu programa de armas nucleares; também avaliamos com confiança de moderada a alta que o governo iraniano pelo menos mantém aberta a opção de desenvolver armas nucleares..."

Mais à frente, a chamada Avaliação Nacional de Inteligência - ANI complementa que: "...A decisão de Teerã de interromper seu programa de armas nucleares sugere que está menos determinado a desenvolver armas nucleares do que temos julgado desde 2005. Nossa avaliação, de que é possível que o programa tenha sido interrompido primordialmente como reação da pressão internacional sugere que o Irã pode ser mais vulnerável a influencia sobre o tema do que avaliamos previamente..."13

Assim, os interesses de Israel aparecem na frente dos interesses nacionais dos EUA, pois secundarizam suas prioridades de dialogo com Teerã em função da beligerância israelense. A valer pelos trabalhos dos Serviços de Inteligência norte-americanos, não a porque temer o programa nuclear iraniano já que sua interrupção foi constatada. A retórica ameaçadora vinda de Washington, Tell Aviv ou Londres não contribui para o solucionar da questão, e ainda anima o discurso agressivo de Teerã que literalmente encontra-se sob ameaça direta das armas nucleares dos EUA e OTAN em suas fronteiras.

Op. Cit. p. 4. 
Artigo original

Hegemonia - Revista Eletrônica de Relações Internacionais do Centro Universitário Unieuro

ISSN: $1809-1261$

UNIEURO, Brasília, número 9, 2012, pp. 68-104.

Ora para que o Brasil se ombreie com os demais atores globais interventores no Médio Oriente, é preciso mais que nunca ponderar os interesses israelenses, sua política regional e seu status de potência nuclear única na região. Paralelamente aos EUA, no Brasil também se encontra um ativo lobby judaico, particularmente no Estado de São Paulo, onde mantém reciprocidade direta com o governo Israelense. Com uma conduta e projeções assimetricamente reduzidas em relação a sua congênere norte-americana, o AIPAC American Israelie Public Assossiation Councill - a Federação Israelita Brasileira atua no sentido de mover a política externa brasileira no Médio Oriente a favor de Israel, por sobre os interesses nacionais do Brasil e da postura pacifica e dialogal da sociedade brasileira. É um fato a existência desse lobby difuso e profuso nas relações externas do Brasil, sobretudo com os países do mundo árabe-muçulmano. Porém há que se lidar com ele, e se o Brasil almeja projeção mais enfática e direta na salvaguarda de seus interesses nacionais no Oriente Médio, deve encará-lo de frente e pesá-lo na balança, certificando se vale a pena quitar potenciais vantagens econômicas, políticas, diplomáticas e sociais pela defesa da política externa de Israel.

\section{O cenário conflituoso: Brasil estabilidade regional X EUA instabilidade regional}

Desde que provocou a militarização do Oriente Médio em 1990, por ocasião da Primeira Guerra do Golfo, os EUA vem sendo acusados pelas sociedades árabes e muçulmanas como o principal fator de instabilidade e insegurança na região. Sua postura intransigente de apoio a Israel, o apoio conferido aos regimes mais retrógados e antidemocráticos - como Arábia Saudita, Jordânia e EAU - as invasões, seguidas de ingente mortandade de civis e destruição material e os bombardeios "seletivos", afora a questão palestina, fazem dos EUA campeões de impopularidade no mundo árabe-muçulmano. Conquanto que o nódulo da questão sejam as relações com Israel, 
Artigo original

Hegemonia - Revista Eletrônica de Relações Internacionais do Centro Universitário Unieuro

ISSN: $1809-1261$

UNIEURO, Brasília, número 9, 2012, pp. 68-104.

Washington deve acalentar os regimes árabes clientes - ou amigos, na linguagem diplomática ${ }^{14}$.

Ao posicionar-se como ator independente na cena regional conflituosa com o Irã, o Brasil necessariamente precisa calcular os nexos da política norte-americana. Nem uma posição endurecida nem uma posição docilizada é o cálculo projetado pela diplomacia em Brasília. Na última rodada coletiva na AIEA sobre o caso iraniano em 2009 (novembro) o Brasil se absteve de votar a condenação contra o Irã encaminhada por EUA e União Européia. Sem gestos abruptos como votar contra ou denunciar a condenação, Brasília procurou o caminho da abstenção como a menor das ofensas. Neste mesmo mês de novembro recebera a visita de Estado de Mahmud Ahmadinejad, logo após sua conturbada vitória eleitoral em julho, e os fatídicos enfrentamentos nas ruas de Teerã. É preciso notar ainda, que também recebera a visita do presidente israelense Shimon Perez no mesmo ano, e aviou a parceria com Israel como sócio externo do Mercosul. ${ }^{15} \mathrm{O}$ comércio bilateral Brasil - Israel alcançou a cifra de U\$ 1.600 milhões em 2008, com acentuado superávit para Israel. Nem por isso deixou de ouvir críticas da Autoridade Palestina, que solicitou o embargo comercial pelo Brasil de empresas e produtos oriundos dos territórios ocupados.

O Brasil se firma também nas relações e intercâmbios com Estados influentes na zona. Com o reino da Jordânia, os dois países acertaram nada menos que 11 acordos nas áreas científicas, tecnológicas e de turismo. Os brasileiros ainda se comprometeram a contribuir para o

Maihold, Gunther. Demasiado Mundo. Op. Cit. p. 3-4.

Biato, Marcel. Por uma Nova Geografia Comercial do Mundo. Revista de Política Externa. Vol. 33. 2010. Diplomata brasileiro, serve no Departamento para Oriente Médio e Norte da África. 
Artigo original

Hegemonia - Revista Eletrônica de Relações Internacionais do Centro Universitário Unieuro

ISSN: 1809-1261

UNIEURO, Brasília, número 9, 2012, pp. 68-104.

aparelhamento, treinamento e eficiência dos corpos de segurança jordanianos, tanto da parte do Ministério da Defesa como do Ministério da Justiça (Polícia Federal). A visita do rei Abdala em 2009 confirmou esta aproximação com um país que é peça chave no conflito israelo-palestino. A prioridade dada pelo Brasil em estreitar os negócios, os intercâmbios e as celebrações coletivas em conjunto - veja a Cúpula América do Sul Países Árabes em 2003 - é um caminho a ser levado a sério nas relações conflitivas do Oriente Médio. A visita do Presidente Lula a países onde a muito tempo não pisava um Chefe de Estado brasileiro, é nota dessa disposição diplomática em apertar as mãos para o convívio num mundo mais multilateral. Revela pois, a busca por um curso mais procedimental nas relações de desavença ou conflitos, prática já experimentada pelo Brasil com sua vizinhança, e nos diálogos com a governança global.

Outra revelação exposta pelo acercamento brasileiro no Oriente Médio, via negócios, é o reconhecimento formal do Estado Palestino em 2011, contra todas as pressões de EUA e Israel. Embora não esteja nos limites desse estudo, as aproximações com a Autoridade Palestina de Mahmud Abbas devem ser colocadas em seu lugar na cena diplomática que envida o Brasil naquela região. Como sócio comercial - apenas daqueles que estão sob a jurisdição da AP - o Brasil confere uma importante oportunidade para que a economia palestina cresça e tome ares internacionais, saindo de seu isolamento. Afora a região oriental de Jerusalém, a Palestina se cambalea com um esquálido mercado interno, produção introvertida, uma quase ausência de exportações além de dependência visceral para com o ocupante israelense. A participação brasileira na economia e junto aos segmentos sociais palestinos, dão um alento para aquela sociedade. E fazem com que o Brasil se credite junto às lideranças palestinas quanto a possíveis acordos conjuntos, baseados nas recentes fórmulas grupais - quartetos, sextetos, etc.

E a ligação existente entre a participação brasileira no cenário geopolítico árabe-muçulmano, mais especificamente com o caso nuclear iraniano, passa pela estrada da Palestina. Sabe-se que Teerã é o principal sustentáculo financeiro e provedor de armas para o 
Artigo original

Hegemonia - Revista Eletrônica de Relações Internacionais do Centro Universitário Unieuro

ISSN: 1809-1261

UNIEURO, Brasília, número 9, 2012, pp. 68-104.

movimento palestino Hamas, que literalmente governa Gaza após a vitória eleitoral em 2008, e cinde a liderança do Fatah na sociedade palestina. Ainda há a presença armada e politicamente atuante do partido Hezbollá no Líbano, atualmente no gabinete ministerial do país. Teerã como fonte de recursos para o partido Hezbollá tem uma ingerência significativa na política libanesa, influindo diretamente na segurança israelense. Sabe-se também que grupos palestinos atuantes no Líbano bandeiam-se a passos largos para o manto protetor iraniano, sejam xiitas ou mesmo sunitas, somando as fileiras do Hezbollá.

O retorno a uma investida do Brasil na geopolítica do Oriente Médio passa por uma solução quanto a esse impasse com o Irã, no sentido de maleabilizar ou mesmo fomentar a unidade entre as duas "bandas" palestinas divididas desde 2008. Nada de movediço busca a diplomacia brasileira ao elencar propostas estabilizadoras com o Irã, na questão palestina ou na questão nuclear, pois ambas encontramse um tanto relacionadas na atual conjuntura. O Itamaraty e 0 próprio Presidente Lula não intentam persuadir Teerã de prescindir sua posição elevada junto ao Hamas, ou renunciar a seu programa de energia nuclear para fins pacíficos. Seria uma deselegância diplomática para com Teerã, ingenuidade política e descredibilização, jogando anos de trabalho brasileiro aos ventos.

Consensuar um acordo seguindo passos jurídicos visíveis e procedimentos expeditivos, é o que intenta realizar a diplomacia brasileira, no mais das vezes empregando a experiência construída nos recentes sucessos conjuntos na América Latina e, sobretudo, na América do Sul. Vincular as pródigas oportunidades de negócios com - Brasil com a disposição diplomática de equilibrar os contrários no Oriente Médio, vem sendo uma seara perseguida pelo país. Para o caso iraniano recente, em que o Brasil fez-se ator de relevo, esta tática persuasiva logrou reconhecimento, da parte iraniana, turca, por sinal e dos Estados árabes em conjunto. Porém como se soube mais à frente, contou com o menoscabo norte-americano e israelense, que não pode, ou não quis ver a chance de se chegar a uma solução mais acorde com o direto internacional e a um convívio regional menos 
Artigo original

Hegemonia - Revista Eletrônica de Relações Internacionais do Centro Universitário Unieuro

ISSN: 1809-1261

UNIEURO, Brasília, número 9, 2012, pp. 68-104.

tenso. Nesta ótica, os EUA e aliados europeus guiando-se sobremaneira pelas lentes endurecidas do direitista governo Likud, travaram as iniciativas tripartites de Brasil, Turquia e Irã, saudadas por atores de peso na região como Arábia Saudita, Jordânia e Rússia mais distante.

A opção militarista, coercitiva e admoestadora conduzida pelos EUA e potências européias, sob os auspícios israelenses, provou ser contraproducente para o caso iraniano, e mais, para a construção equilibrada de um modus vivendi com a República Islâmica. Como tem advertido a Rússia, tanto sob a presidência Putin como sob a atual de Medvedev, o esgotamento do regime de sanções já é uma realidade. Insiste e advoga por um diálogo aberto e franco, onde a parte iraniana seja legitimada em seus anseios por empregar a energia nuclear para fins que não sejam militares. No teatro políticodiplomático das Nações Unidas e AIEA, orquestrado em grande medida pela maquinaria ideológica de EUA, União Européia e Israel, vê-se que não há mais espaço para as conversações positivas que induzam o avanço negociador. A alusão que fez o presidente Lula em entrevista sobre o comportamento incompreensível dessas potências ocidentais, afina com a posição de Moscou:

"...não querem a solução da questão nuclear iraniana, querem sua otimizaçãop para os fins militaristas típicos, como se viu a bem pouco tempo..."16

Outro nível contraproducente a que chegou a atividade de EUA e aliados europeus para o caso iraniano, são as sanções unilaterais desfechadas à revelia das Nações Unidas. Insiste Moscou que qualquer medida extrema que se adote contra o Irã - como exemplo as sanções políticas e econômicas - devem ser deliberadas e aprovadas no marco multilateral do Conselho de Segurança da ONU.

Correio Braziliense. $\mathrm{N}^{\circ}$ 1133. 15/06/2010. Página Internacional. A previsão de Lula sobre o futuro do Oriente Médio. 
Artigo original

Hegemonia - Revista Eletrônica de Relações Internacionais do Centro Universitário Unieuro

ISSN: 1809-1261

UNIEURO, Brasília, número 9, 2012, pp. 68-104.

Em recente intervenção pública, Serguei Lavrov, chanceler russo, aponta para a perda de legitimidade por parte de Washington e União Européia perante Teerã, devido às posições unilaterais sem qualquer traço de profissionalismo producente. ${ }^{17}$ Neste parecer russo, a posição do Brasil sintoniza-se mais com a de Moscou que com a dos tradicionais aliados europeus e norte-americano, denotando a postura pragmática, e sombranceira a matizes ideológicas.

Também a postura da China, ombreia com as posições do Brasil. Como sócio comercial importante do Irã, parceiro inovador no cenário geopolítico do Oriente Médio e membro permanente do CS da ONU, as declarações oficiais de Pequim são observadas com atenção. A China faz elevada aposta em que os dínamos do comércio e negócios que mantém com o Irã sejam uma barreira de contenção à política ocidental de "ilhar" o gigante centro-asiático. Na atual conjuntura, o Irã já é o segundo maior exportador de petróleo para a China, superando Angola, e mantendo-se ligeiramente atrás da Arábia Saudita. A valer pelos ímpetos comerciais entre os dois países, para o biênio 2012-2013 o Irã superará a Arábia Saudita, devido à rede de oleodutos sob o Cáspio que projetam russos e chineses, com o concurso iraniano. Saldo maior: a Bolsa Petrolífera do Golfo, inaugurada por Teerã em 2010, é reconhecida oficialmente pela China, Rússia, e outros clientes da energia iraniana - Turcomenistão, Paquistão, Índia, entre outros - que fazem inversões e cotizações. Ainda a preferência monetária de Teerã é em Euro, Rublo, Renmimbi chinês e outras moedas de valor no mercado mundial, secundarizando a moeda norte-americana. O Brasil se mostrou interessado em investir na Bolsa do Golfo, e ao que tudo indica, não demorará em fazê-lo.

Agência de Notícias russa Ria Novosty. Entrevista concedida pelo Ministro de Exteriores Serguei Lavrov. Disponível em: www.rianovosty.sp/internacional/acerca/ira. Em espanhol. 
Artigo original

Hegemonia - Revista Eletrônica de Relações Internacionais do Centro Universitário Unieuro

ISSN: $1809-1261$

UNIEURO, Brasília, número 9, 2012, pp. 68-104.

O contexto político no qual o Brasil tende a se afiançar no Oriente Médio passa pelas relações comerciais e de negócios, não importando muito a coloração midiatizada que se faz para este ou aquele Estado. Neste propósito, o protagonismo brasileiro choca-se com a postura militarista, beligerante e pouco tratável de Washington e aliados europeus, reunidos na cambaleante Eurozona. Mesmo assim, a Casa Branca não titubeou em convidar o ocupante do Palácio do Planalto em Brasília para uma empreitada em que seus esforços se mostraram inúteis. O desembarque do Presidente Lula e do Premiê turco Racyp Erdogan à capital iraniana, portando aspirações globais de um desfecho satisfatório para o "caso nuclear" iraniano, estava em comum acordo com a administração Obama. Resta todavia, uma incógnita a respeito do vôo diplomático sui generis alçado pelo Brasil e seu presidente em maio de 2010: porque escolher um Estado politicamente tão distante da cena geopolítica do Oriente Médio, e mais, porque oportunizar um Estado que recentemente vem se revelando incongruente com as políticas unilaterais de EUA e União Européia no tabuleiro geopolítico iraniano?

\section{O convite e o passaporte dos EUA para o Brasil e Turquia}

Segundo as autoridades diplomáticas brasileiras e turcas, partiu do presidente norte-americano Barack Obama a solicitação para os líderes de Brasil e Turquia intervirem no caso nuclear iraniano. ${ }^{18}$ Seguidamente as jornadas diplomáticas empreitadas por Washington, Londres, Paris e Berlim por um lado, pelo organismo internacional de energia atômica - AIEA - por outro, além de Moscou, que conformam o chamado Sexteto para o caso nuclear do Irã, não surtiram efeito positivo. Neste trânsito diplomático e político que se seguiu os Brasília, DF.

Revista Brasileira de Política Internacional. Vol. 33. Agosto-setembro de 2010. FUNAG. 
Artigo original

Hegemonia - Revista Eletrônica de Relações Internacionais do Centro Universitário Unieuro

ISSN: 1809-1261

UNIEURO, Brasília, número 9, 2012, pp. 68-104.

membros europeus e norte-americano adotaram certa razoabilidade para recorrer a parceiros próximos do Irã, como Brasil e Turquia. 0 fato de não oportunizarem Estados mais próximos, como China, Rússia - que é parte do Sexteto - ou Síria, causou estranheza para muitos analistas, devido a uma razoável chance sucesso.

Em observação das tratativas na arena geopolítica contemporânea, muito singular e sem comparações com outros casos do passado, a probabilidade de Washington e Bruxelas de conferir notoriedade a um desses Estados "amigos" do Irã de celebrar qualquer acordo juridicamente factível com Teerã, seria bastante remota. Sim porque tanto China, como Rússia são potências que desafiam e põem em cheque a já antiga hegemonia euro-americana na Ásia. E ainda concorrem com o bloco ocidental pela maior influencia possível sobre as imensas riquezas energéticas na Ásia Central, da bacia aralo-caspiana, e dos corredores de pipelines que percorrerem esta grande região euroasiática. ${ }^{19}$

Portanto é indefectível a constante e evolutiva presença sinorussa na Ásia Central e nos contrafortes dos Himalaias, em que pese a militarização levada a cabo por Washington e aliados da OTAN. Daí que uma investida diplomática dessas duas grandes potências, ou de Estados próximos como Síria, seria absolutamente inconveniente para EUA e União Européia. Não contariam, como de fato não contaram com o beneplácito da chamada comunidade internacional - leia-se bloco ocidental - que em todo caso vetariam qualquer iniciativa conjunta e multilateral que Moscou e Pequim construíssem para o problema nuclear iraniano.

Então haveria de se buscar noutros horizontes a disponibilidade necessária que satisfizessem EUA e União Européia, em primeiro plano, aliados clientes árabes em segundo e Rússia e China em

Chossudovsky, Michel. La Nueva Ruta de La seda. Disponível em: www.globalresearch.ca/2010. 
Artigo original

Hegemonia - Revista Eletrônica de Relações Internacionais do Centro Universitário Unieuro

ISSN: 1809-1261

UNIEURO, Brasília, número 9, 2012, pp. 68-104.

terceiro. A escolha recaída em Brasil e Turquia não foi nada casual e estanque das querelas políticas recentemente implantadas no Oriente Médio pela ação de EUA e europeus. O convite ao Brasil repousa na acomodação política e diplomática com que o país vem se estabelecendo na região, já observada mais atrás neste estudo, e que merece apenas um adendo. A diplomacia presidencial referendada na liderança multilateral que evidencia o presidente Lula, em quase todos os quadrantes do mundo. Em seu continente americano e subcontinente sul-americano, na África, na Europa, na China e por último no Oriente Médio, o traço brasileiro é marcado pela liderança de seu presidente, acorde com uma política procedimental habilidosa, operando tudo no marco do diálogo e dos compromissos firmados. Mandando aos ares qualquer forma de ideologia, estereótipos, inclinações e simpatias, o Brasil assume um interessante mecanismo pragmático de lidar com os opostos, e tem se saído bem nos casos onde atua. Pode muito bem ser esta a razão, ou uma das razões que moveram EUA e União Européia a trabalhar o concurso brasileiro no caso nuclear iraniano, através de sua diplomacia presidencial.

Por não existirem atritos novedosos, pendores históricos, e, sobretudo descredibilização do Brasil com qualquer dos Estados da zona, particularmente com o regime de Teerã, a escolha foi certeira e estratégica. Ver-se-á mais a frente. Agora, uma outra atenção recai no segundo ator escolhido pela dirigência euro-americana: a Turquia. Desde que assumiu o poder a inícios da década (2001) o Partido da Justiça e Cidadania, AKP, de inspiração islamista, tem conferido um toque regionalista e autonomista em sua política exterior. Na visão de alguns analistas, o enfoque iniciado por Erdogan e seus dois ministros de exteriores, Abdala Gull, hoje presidente da república, e o atual chanceler, Ahmet Davotuglu, caracteriza-se como o "neo-otomanismo" turco. ${ }^{20}$

Rozzof, Rick. La Emergencia de Turquía em el mundo Multipolar. Disponível em: www.globalresearch.ca 2011. 
Artigo original

Hegemonia - Revista Eletrônica de Relações Internacionais do Centro Universitário Unieuro

ISSN: $1809-1261$

UNIEURO, Brasília, número 9, 2012, pp. 68-104.

Por isso é patente a escolha de Ankara em voltar as atenções privilegiadas em sua política externa para seus vizinhos, neutralizando antigos atritos e questões latentes, como a Armênia. As relações com o Irã se deterioraram muito depois da Revolução Islâmica de 1979, mas também é verdade que nenhuma agressão ao país persa foi verificada vindo de Ankara. Por disporem de fronteiras comuns carregadas com problemas similares, ambos os governos tem buscado um diálogo mais proativo em beneficio mútuo, cujo epicentro problemático é o irredentismo curdo. Este é alvo das constantes operações efetivadas por forças turcas e iranianas, em suas respectivas áreas fronteiriças, porém desde meados da década, por operações conjuntas. A colaboração entre Teerã e Ankara na pacificação territorial intrafronteiras torna-se sumamente importante para os dois países, na medida em que sofrem com separatismos e integrismos étnicos e religiosos, muitas vezes respaldados do exterior. Soma-se ao fato de serem fisicamente as maiores potências da grande região Médio Oriental, com as maiores populações, parques industriais complexos, forças armadas e territórios.

Porém chama atenção a aproximação turco-iraniana pelo seguinte, em se tratando do aspecto histórico recente: a República Turca é um membro pleno da OTAN, com o terceiro maior exército, tradicional aliado dos EUA e Grã Bretanha, perpétuo candidato ao bloco europeu, e aliado das potências regionais chave para 0 Ocidente, Israel e Arábia Saudita. Tradicionalmente, Ancara nunca se acercou ao autonomismo nacionalista iraniano ou sírio, mal visto por Washington e Londres, sobretudo. As investidas protagonizadas pela Turquia no Oriente Próximo eram determinadas pelo consenso com as grandes potências ocidentais, mais Israel, favorecendo as políticas conservadoras, e minando sempre que possível os arroubos nacionalistas árabes. Entende-se esta postura turca como expressão das tendências políticas internas, em virtude de seu republicanismo autoritário - o kemalismo - liderança política das forças armadas ocidentalizadas, uma elite econômica liberal integrada no sistema europeu, e um governo acorde com o establishment global. 
Artigo original

Hegemonia - Revista Eletrônica de Relações Internacionais do Centro Universitário Unieuro

ISSN: 1809-1261

UNIEURO, Brasília, número 9, 2012, pp. 68-104.

Com as vitórias eleitorais das forças nacionalistas e islamistas lideradas primeiro pelo falecido ex premiê Nectmedin Erbakan, e posteriormente pelo seu herdeiro, o atual primeiro ministro Racyp Erdogan, a Turquia sofre uma inflexão, e desponta como sujeito ordinário de seus interesses. É aí que os nódulos com os vizinhos são recompostos, agora numa atmosfera mais regionalista que internacionalista, e menos sujeitada aos interesses exógenos da sociedade turca. Neste cenário inovador e renovador é que são estabelecidos os atuais nexos entre a Turquia neo-otomanista e a República Islâmica do Irã. Nexos alicerçados no pragmatismo político, nos interesses mútuos de segurança e estabilidade regional, mecanismos formais de comunicação e integração intergovernamental e ainda, expansão dos negócios. Como mostra o quadro abaixo, os intercâmbios comerciais e os investimentos entre Turquia e Irã são constantemente ascendentes desde a chegada do AKP ao poder, seguido de intensas transações populacionais. Pela primeira vez em mais de trinta anos, as fronteiras são abertas plenamente entre os dois países, facilitando o tráfego de pessoas, e riquezas de um lado a outro.

Portanto não é casual a investida diplomática turca no caso nuclear iraniano. Responde as grandes linhas regionalistas traçadas por Ancara com sua vizinhança imediata, onde no dizer do chanceler Ahmet Davotuglu, "...zero problemas com nossos vizinhos..." A despeito das imbricadas relações já antigas da república turca com o Ocidente, o neo-otomanismo está bem mais voltado para a construção de uma política externa e regional que priorize os interesses nacionais turcos. Neste sentido, a expansão econômica, 0 deslocamento industrial europeu para o país, com o conseqüente aumento das exportações de manufaturados, a instalação de indústrias turcas no entorno - Síria, Líbano, Irã, Jordânia - e as exportações de capitais, via IDEs, créditos e finança, tem entusiasmado a elite dirigente turca. Não são vantagens que Ancara renunciará tão facilmente em proveito de uma geopolítica belicista e 
Artigo original

Hegemonia - Revista Eletrônica de Relações Internacionais do Centro Universitário Unieuro

ISSN: 1809-1261

UNIEURO, Brasília, número 9, 2012, pp. 68-104.

anti-econômica proposta pelo conglomerado EUA-União EuropéiaIsrael. $^{21}$

Todavia, dadas as relações e a aliança de longa data mantidas com o bloco ocidental, mormente EUA e Reino Unido, Ancara não pode deslindar uma petição vinda de Washington. O "convite" endereçado conjuntamente ao Brasil, revela que para EUA e aliados europeus, a Turquia neo-otomana é ao mesmo tempo uma aliada in loco, e também uma incógnita, que pode ser melhor revelada frente uma empreitada de peso como o acordo tripartite com Teerã. Seguro está que o atual regime do AKP não é um todo homogêneo, sofre rusgas internas como qualquer regime, sobretudo na instável e alvejada região do Médio Oriente. É precisamente nas dissenções internas que age a política interventiva de Washington, para assegurar vantagem sobre o terreno de seus aliados mais chegados no establisment turco. No caso, as forças armadas e o empresariado transnacional, típicos representantes dos interesses globalistas no país, e os movimentos sociais de base, mais as classes produtivas internas, representando a vertente nacional e regional do AKP. Se logra vitória internacional a iniciativa com Teerã, ponto para os segundos, se malogra, ponto para os primeiros, que nada tem de simpáticos ao regime iraniano.

Contudo, em razão das eleições parlamentares turcas celebradas em outubro de 2011, com significativa vitória do AKP, e permitindo a Erdogan renovar seu mandato por mais quatro anos, os planos de Washington para a Turquia, não deram resultado positivo. Sobressai-se dessas eleições, a vertente nacionalista no seio do AKP, que mantém vivo o acordo tripartite com Teerã e Brasil - não obstante o rechaço anglo-americano. Sobressai-se ainda a opinião pública interna favorável, que ratifica cada vez mais a política externa

Danucci, Manlio. Las bromas del alineamiento ocidental de Turquía. La Nato em questión. Disponível em: www.redvoltaire.org.es/hojadiplomatica 2011. Em espanhol. 
Artigo original

Hegemonia - Revista Eletrônica de Relações Internacionais do Centro Universitário Unieuro

ISSN: $1809-1261$

UNIEURO, Brasília, número 9, 2012, pp. 68-104.

independente e pró-ativa de seu governo. Precisamente, a escolha de Washington como membro do Sexteto, de Turquia e Brasil para um possível acordo com Teerã foi exitosa, na medida em que o respaldo internacional foi válido. E ainda foi válida a aquiescência do Irã em permitir o enriquecimento de urânio no estrangeiro, nos limites da produção de energia para suas necessidades (medicinais e consumo). Assim sendo, todos os requisitos para um acordo a nível global foram alcançados. Contudo o rechaço por parte de EUA e aliados europeus, leva a crer que os planos traçados não contemplavam qualquer consenso com vistas à estabilizar a situação. Mais se crê que são planos agressivos, beligerantes, que buscam na intimidação realizar metas de hegemonia não compatíveis com o nível de independência a que se chegou esses três atores estatais emergentes. ${ }^{22}$

Ora, tanto Turquia como Brasil, saíram fortalecidos política e diplomaticamente desse acordo Tripartite acertado com o Irã. O fato de haver tido a desconsideração de Washington e aliados europeus no Sexteto, e partir para o endurecimento contra o regime islâmico, mostra a pouca disposição para o entendimento multilateral dessas potências. O discurso da embaixadora brasileira no Conselho de Segurança das Nações Unidas Maira Luísa Viotti, deu o tom mais que claro na reunião que se seguiu ao anúncio do acordo e o concomitante rechaço euro-americano:

"... Este conselho perdeu uma importante chance de se chegar a um fim positivo, e em troca, escolheu um futuro incerto e temeroso...(...) Estamos votando contra por não vermos as sanções como instrumento eficaz neste caso. As sanções, muito provavelmente, levarão ao

Op. Cit. No texto, Danucci que é jornalista e não analista político, tem a preocupação de relatar os desafios e as barreiras colocadas por Irã e Turquia a seus respectivos aliados poderosos, Rússia e EUA respectivamente. É uma reedição das antigas barganhas dos não-alinhados com os blocos amigos no tempo da Guerra Fria. 
Artigo original

Hegemonia - Revista Eletrônica de Relações Internacionais do Centro Universitário Unieuro

ISSN: $1809-1261$

UNIEURO, Brasília, número 9, 2012, pp. 68-104.

sogrimento do povo iraniano e serão usadas por aqueles que, em todos os lados, não desejam a prevalência do diálogo..."n3

As políticas concertadas por Brasília e Ancara revelaram maturidade política, disposição ao diálogo pragmático e procedimental, e superaram contradições internas, em parte carregadas com tinta midiática e ideológica. É o caso da grande imprensa brasileira que por dias vociferou contra o acordo tripartite. O próprio governador de São Paulo José Serra, presidenciável, demonstrou pouca afinidade diplomática para um pretendente ao cargo de presidente, quando considerou que

"... É repugnante que o Brasil receba o chefe de regime ditatorial e repressivo. Uma coisa é manter relações diplomáticas com ditaduras, outra receber a seus chefes em nosso país..."24

A visita de Estado do presidente Ahmadinejad, em novembro de 2009, causou uma espécie de histeria na grande imprensa brasileira, seguido em certa medida por destacados intelectuais e porta vozes dos direitos humanos no país. Argumentavam no mesmo tom do governador paulista, e outros iam mais longe, como o jornalista Cláudio Humberto, comentarista da rádio Band News, que disparou contra o líder iraniano acusando-o de belicista e criminoso que

Viotti, Maria Luísa Ribeiro. Intervenção da Embaixadora do Brasil no CS da ONU. In: www.itamaraty.gov.br/sala-de-imprensa/notas-a-imprensa/intervencao 09/06/2010 
Artigo original

Hegemonia - Revista Eletrônica de Relações Internacionais do Centro Universitário Unieuro

ISSN: $1809-1261$

UNIEURO, Brasília, número 9, 2012, pp. 68-104.

haveria de ser detido no país e remetido à justiça internacional em Haia.

Também na Turquia alguns setores reagiram de forma negativa, porém menos agressiva e menos irrealista que parte considerável da sociedade civil e política brasileira. Não apenas pela vizinhança e novas pontes erguidas entre os dois países, más por uma história compartida a séculos, turcos e iranianos não tem porque se estranharem e criarem estereótipos ficcionais um com o outro. Isso levando-se em consideração a rivalidade secular mantida outrora entre os dois maiores impérios do mundo muçulmano, o persa e o otomano, por maior influência sobre a casa do Islã. Basicamente alguns quadros das forças armadas turcas, possivelmente alinhados com os preparativos militaristas de Washington e Londres, e o ramo mais ortodoxo da liderança sunita em Istambul, historicamente hostil a teocracia xiita em Teerã. ${ }^{25}$

Portanto Brasil e Turquia tiveram de superar suas contradições internas para garantir sua parcela no avanço internacional do multilateralismo, apesar de levar a termo uma solicitação norteamericana. Mesmo diante das críticas no seio de sua opinião pública, o presidente Lula dispôs-se a estabelecer pontes de diálogo com seu colega iraniano, na busca efetiva de uma solução comum a todos para o caso nuclear do país. Más, se setores se indispuseram com a empresa diplomática, uma maioria significativa dos partidários do PT e demais siglas coligadas com o governo Lula rederam apoio à iniciativa do presidente. Meios de comunicação de abrangência nacional no Brasil, e analistas também aprovaram a iniciativa, que se tornou já um marco na história das relações internacionais do Brasil. Aponta para a inserção crível do país nesta parte estratégica e vital do mundo, e graças à lógica autonomista guindada pelo Planalto,

Chossudovsky, Michel. Op. Cit. p. 5-6. In: www.globalresearch.ca/pipelines/iran. 2011. Talvez a sensível casta dos mulás de Istambul se sinta reduzida em influência política e poder no islamista governo turco do AKP em comparação com sua congênere iraniana. 
Artigo original

Hegemonia - Revista Eletrônica de Relações Internacionais do Centro Universitário Unieuro

ISSN: 1809-1261

UNIEURO, Brasília, número 9, 2012, pp. 68-104.

uma inserção livre de receios, de inclinações ideologizadas e multilateral.

\section{Brasil e Irã no contexto da globalização inclusiva}

Tanto a República Islâmica do Irã como o Brasil representam respectivamente duas grandes economias em expansão, emergentes, e com considerável influência em suas zonas subcontinentais. A diferença nos dois casos, está mais no contexto geopolítico que na dimensão de ambos os países. Sim, porque o Brasil não precisa se fortalecer demasiadamente em áreas como defesa e dissuasão para levar a cabo sua expansão econômica e melhorias sociais para sua população. Seu crescimento, conta com o beneplácito não concorrente dos EUA, na América Latina e do Sul. Aos olhos de Washington e dos demais Estados do continente, o Brasil não representa uma ameaça à ordem democrática e liberal projetada para as Américas nas séries de conferencias e acordos multilaterais celebrados desde a Iniciativa para as Américas de George H. Bush, em 1991.

Os ingentes esforços para o desenvolvimento buscados tanto por Brasil quanto pelo Irã são congruentes com as políticas inclusivas e desenvolvimentistas exercitadas por seus governos. Contudo o país persa esbarra-se no não menos ingente esforço de garantir segurança suficiente para sua população - 70 milhões - em trilhar os rumos do desenvolvimento estável e pacífico. A estima com os gastos em defesa são da ordem de $30 \%$ do PIB iraniano, mais os suplementos não divulgados. É uma soma assombrosa que certamente extrai parte importante dos recursos públicos que deveriam ser destinados ao incremento material e humano do país. Doravante a destruição do Estado laico iraquiano, obstáculo exponencial para a hegemonia norte-americana na região, as atenções de Washington, e aliados ocidentais, detém-se para a República Islâmica. Por quase uma década - 2003/2011 - o Irã adjudica seus recursos à indústria de defesa, russa em grande parte, 
Artigo original

Hegemonia - Revista Eletrônica de Relações Internacionais do Centro Universitário Unieuro

ISSN: $1809-1261$

UNIEURO, Brasília, número 9, 2012, pp. 68-104.

e coloca parte substancial do parque produtivo e tecnológico a subsidiar este incremento.

Mas as afluências entre Brasil e Irã vem num ritmo crescente e não fosse os embargos e a política de isolamento promovida por EUA e União Européia, os dois países seriam dinâmicos parceiros. O Irã conta com uma tradição de negócios e amplitude comercial de longa data, além de prescrever uma política preferencial com os Estados em desenvolvimento. Desde as reformas de Muhammad Mossadegh nos anos 1950, abortadas a golpe por EUA e Reino Unido, que o país inclina-se para os "grandes da periferia" como alternativa à uma economia tributária das grandes potências. Seja Reino Unido, EUA, França ou mesmo a URSS, o Irã rotineiramente buscou diversificação em suas relações, isso mesmo sob o regime pró-ocidental do Xá Reza Pahlevi. ${ }^{26}$

O comércio bilateral Brasil-Irã é o segundo maior de toda a região do chamado Grande Oriente Médio, que abrange o Magreb e o Mishrek africanos, o Oriente Próximo, a Península Arábica, a Mesopotâmia, e a Ásia Central (Irã, Afeganistão e Paquistão). Logo abaixo da Arábia Saudita, que importa vultuosas manufaturas alimentícias e aviões para uso civil, vem o Irã como principal parceiro do Brasil. Isso sob os regimes asfixiantes das sanções, sejam elas unilaterais ou respaldadas pela ONU.

Os dados acima foram extraídos do sítio do MDCI, Ministério da Indústria e Comércio Exterior, e dão nota para o comércio bilateral em expansão. ${ }^{27}$ Informa-se apenas 0 volume das exportações

Amin, Samir. Os Desafios da Mundialização. Tradução: Ivo Storniolo. Aparecida, SP: Idéias e Letras. 2006. Para Amin: os EUA e a URSS ergueram o fenômeno conhecido por bipolaridade (...) Porém para certos Estados ao mesmo tempo grandes e estrategicamente posicionados, como o Egito de Nasser, o Irã, a India e a China, puderam lançar de mão de políticas autonomistas graças a sua importância vital para as duas superpotências. P. 47-48.

\footnotetext{
Ministério do Desenvolvimento Indústria e Comércio Exterior. Disponível em: www.mdic.gov.br/export/brasil. 2010.
} 
Artigo original

Hegemonia - Revista Eletrônica de Relações Internacionais do Centro Universitário Unieuro

ISSN: 1809-1261

UNIEURO, Brasília, número 9, 2012, pp. 68-104.

brasileiras para o Irã. A primeira coluna são as exportações totais do Brasil para o Irã em bilhões US\$; a segunda coluna são as variações sofridas; a terceira coluna as exportações de produtos básicos, in natura; em quarto as variações anuais sofridas; a quinta coluna são as exportações de produtos industrializados, semi-acabados e integralmente manufaturados. Uma suscinta leitura desses números e percebe-se que o regime de sanções fez efeitos entre 2009 e 2010, época de sua entrada em vigor. Veja que as variações anuais seguem um curso ascendente, com média elevada nas exportações até 2009. A partir daí, as variações vão diminuindo, para se chegar a números relativamente modestos ao fim do ano 2011. Números não compatíveis com a curva ascendente das exportações em anos anteriores. Também em virtude das sanções os valores exportados em bens agro-minerais baixam, pois acreditam os mandatários da ONU, que uma infinidade de recursos naturais podem ser utilizados no programa nuclear do país. Isso afeta justamente a corrente exportadora mais importante da economia brasileira, a da indústria agro-mineral.

Contudo, apesar da tensão em manter relações comerciais com o Irã, ao cabo de 2010 os números foram expressivos: mais de US\$2 bilhões de dólares exportados para o país persa, 74\% de aumento nas vendas em relação ao ano anterior (2009). Não é casual ou parte de uma simpatia ideológica o que motivou o Brasil a votar contra o regime de sanções no Conselho de Segurança das Nações Unidas. Trata-se aqui de interesses bem explícitos e que são dirigidos ao robustecimento industrial brasileiro, num país proclive ao comércio e aos investimentos com o Brasil. O Brasil, ou melhor, seus setores produtivos, ressentiram-se dessas medidas draconianas que privam 0 expansionismo econômico brasileiro num período de crise global. Embora os números acima não retratem, mas a gama de produtos exportados ao Irã vinha celeremente se diversificando, abrangendo cada vez mais uma pauta variada. Implica que mais setores 
Artigo original

Hegemonia - Revista Eletrônica de Relações Internacionais do Centro Universitário Unieuro

ISSN: $1809-1261$

UNIEURO, Brasília, número 9, 2012, pp. 68-104.

produtivos e ramais complementares da cadeia industrial se incorporavam nas relações comerciais com o país asiático. E tal tendência era positiva, como soe informar o quadro acima.

Daí que as relações com o Irã são vantajosas para o Brasil, tanto economicamente quanto geopoliticamente. Na conjuntura presente a necessidade dos "gigantes emergentes" em selar acordos para a manutenção de um crescimento sólido e constante é categórica. A crise financeira global, cujo efeito mais danoso é o rentismo financeiro improdutivo, que desemboca na paralisia dos setores produtivos, encontrará como escape virtuoso a produtividade, com geração de emprego e renda. ${ }^{28}$ Segundo o professor Michel Hudson, a aparente incolumidade dos grandes Estados do sul está em não adotarem o rentismo finceiro como dádiva para suas sociedades. Ao contrário tem se esforçado por manterem os níveis de produtividade, cada qual a sua maneira, sem colapsar suas estruturas geradoras de riqueza. Se deve em parte aos acordos inter-blocos onde procuram minar os efeitos da crise voltando-se para suas vantagens comparativas: China-MERCOSUL, BRICS, Organização de Cooperação de Shangai (OCS), Rússia-China. São os Estados emergentes de franco desenvolvimento que poderão debelar a presente crise econômico-financeira, cujo epicentro está no 'Primeiro Mundo'. Assim, é digno de nota o fator geopolítico que impregna as relações de duas grandes potências emergentes como Brasil e Irã no contexto atual global. E também é digno de nota como as velhas potências, ainda detentoras de supremacia numa ONU que requer urgentemente por mudanças, podem influir negativamente nesse concerto geoestratégico emergente. Segundo o analista norteamericano Rick Rozoff

Hudson, Michel. O Sul não deve adotar o modelo dos países ricos. Disponível em: www.resistir.info Em português. 
Artigo original

Hegemonia - Revista Eletrônica de Relações Internacionais do Centro Universitário Unieuro

ISSN: $1809-1261$

UNIEURO, Brasília, número 9, 2012, pp. 68-104.

"... Sobre a base deste crescente peso econômico e militar dos últimos anos, que os governos turco, brasileiro e iraniano, levam tempo consolidando-se como potências regionais influentes. (...) Não há como desconsiderar seus interesses para todo e qualquer futuro que se pretenda construir nas regiões em que respectivamente se encontram... ${ }^{129}$

Portanto as relações em ascenço entre Brasil e Irã continuarão, salvo uma catástrofe abater-se, como advogam os prelúdios de guerra contra a República Islâmica. Mesmo assim a posição brasileira é coerente com seus interesses nacionais e corrobora o multilateralismo ascendente, que previne contra agressões armadas ou veladas para a resolução de conflitos. Deixa-se claro o fato de que ao Brasil não lhe consta o absolutismo de seus interesses nacionais por cima da lei e do direto internacional. Brasília busca nas interventivas com o Irã, em parceria com demais atores - Turquia, China, Rússia, Brics - uma superação baseada em procedimentos diplomáticos e políticos transparentes, assentados no direito internacional e na autodeterminação dos povos. É um desafio hercúleo sobrepor procedimentos diplomáticos convergentes para a resolução, diante de ressonâncias agressivas palpitando a todo momento.

E consensuar os interesses basicamente pacíficos, que movem as relações entre Brasil e Irã (comércio, IDEs, transações, créditos, multilateralismos) com as táticas duras movidas por EUA e União Européia, tradicionais aliados do Brasil, não é tarefa fácil. Tanto a outrora diplomacia presidencial brasileira, como a convencional Itamaraty - precisam se municiar de todas as razões possíveis para fazer entender a seus parceiros mais agressivos, que o Brasil não

Rozoff, Rick. El Ascenso de Poderes Regionales? El Nuevo Fundamentalismo Islámico. In: www.globalresearch.ca/index/rickrozoff 19/08/2010. 
Artigo original

Hegemonia - Revista Eletrônica de Relações Internacionais do Centro Universitário Unieuro

ISSN: $1809-1261$

UNIEURO, Brasília, número 9, 2012, pp. 68-104.

admitirá retrocesso em sua trajetória para o desenvolvimento; nem tampouco consentirá com políticas que desestabilizem Estados parceiros, sócios no crescimento no desenvolvimento com o Brasil. E como também lembrado atrás, não pode prescindir das tradicionais e antiqüíssimas parcerias com União Européia e EUA, alavancas em muitos aspectos do crescimento brasileiro, e países com os quais o Brasil guarda profundos laços com suas sociedades.

É o desafio do momento para o Brasil emergente e postulante ao primeiro nível das potências mundiais.

\section{A efetividade dos acordos tripartite, no marco presente}

A votação das sanções contidas na resolução 1929 de 09/06/2010, em matéria técnica não lograram o êxito esperado. Isso porque a rejeição adotada como práxis política por EUA e potências européias em tudo que acerca a uma acomodação com o Irã parece ser a lógica encomendada. Mesmo após a Declaração Conjunta de Teerã firmada em maio de 2010, ante as exigências do Grupo de Viena, a posição das autoridades ocidentais foi de um ceticismo deliberado. Este chamado Grupo de Viena, é instrumento técnico que acompanha o caso nuclear iraniano desde 2006, e vem sendo o marco regulatório para as manifestações do Organismo Internacional de Energia Atômica - AIEA - e também das Nações Unidas. Ocorre que as intervenções protagonizadas por Washington, Londres e Paris, frustram as realizações profissionais desse Grupo de Viena, tornandoo mais uma arena política que instrumento diplomático.

Após os esforços de Brasil e Turquia no correr do ano de 2009, surge a Declaração de Teerã em 17 de maio de 2010, que mais uma vez, segundo a embaixadora brasileira no CS

"... alcançou uma solução que permitiria ao Irã exercer plenamente seu direito ao uso pacífico da energia nuclear, 
Artigo original

Hegemonia - Revista Eletrônica de Relações Internacionais do Centro Universitário Unieuro

ISSN: $1809-1261$

UNIEURO, Brasília, número 9, 2012, pp. 68-104.

ao mesmo tempo que daria garantias plenamente verificáveis de que o programa nuclear iraniano tem propósitos exclusivamente pacíficos..." ${ }^{130}$

Contudo o establishment político norte-americano e europeu não reconheceu tal fato e materializou as mais duras sanções já aplicadas ao país persa. Pela denúncia de Ancara e Brasília, não houve sequer tempo hábil para que Teerã examinasse as diretivas elaboradas pelo Grupo de Viena, reação à Declaração de 17 de maio. Fruto de um esforço comum, principalmente de Brasil e Turquia, a Declaração não foi levada a sério pelas potências representadas no Sexteto, e põem em xeque a credibilidade desses governos no caso iraniano. Resumidamente, os acordos previam o que vinha sendo demandado tanto pelo Sexteto, quanto individualmente por EUA e União Européia, mais alguns Estados do Golfo e Israel, que era a troca do urânio enriquecido em território iraniano por energia nuclear equivalente, destinada a fins civis. A Declaração convinha ainda mais as expectativas internacionais quando franqueava às autoridades da AIEA as instalações nucleares iranianas, no mesmo ritmo convencional aplicado a outros Estados, ou seja, seguindo um calendário padrão.

O tom acusatório com que o Brasil reagiu a resolução 1929, foi imperioso ao taxar as partes envolvidas. Sim porque todos os atores tinham conhecimento pleno dos avanços perseguidos e conseguidos mediante a senda tripartite encabeçada por Brasil, Turquia e Irã. Não conceder o tempo necessário, típico em negociações como esta, é simplesmente desmantelar o acordo antecipadamente. E mais, é politizar uma questão por demais politizada que não encontra paralelo nas mais recentes empreitadas do Conselho de Segurança, salvo nos casos líbio e sírio mais correntes. Assim as acusações de 
Artigo original

Hegemonia - Revista Eletrônica de Relações Internacionais do Centro Universitário Unieuro

ISSN: $1809-1261$

UNIEURO, Brasília, número 9, 2012, pp. 68-104.

Brasília, primeiro, e Ancara um dia depois da votação da 1929, simboliza um corte na disposição de forças na ONU, e mais além, no tabuleiro internacional. Isso em se tratando de dois Estados reconhecidos por sua aquiescência nas elaborações européias e norte-americanas, aliados de longa data de EUA e União Européia, com sociedades em muitos aspectos ocidentalizadas.

Ora as acusações disparadas pelo Brasil não deixam dúvidas quanto a este "corte" no teatro geopolítico global principiado no CS das Nações Unidas:

"... A adoção de sanções em tais circunstâncias envia um sinal errado ao que poderia ser o começo de um engajamento construtivo em Viena, e marco nas resoluções de conflitos (...) Também objeto de grave preocupação foi a maneira pela qual os membros permanentes, juntamente com um país que não é membro permanente do Conselho de Segurança (Alemanha) negociaram entre si, por meses e a portas fechadas... ${ }^{131}$

Mesmo que os acordos estejam em hibernação no presente, as iniciativas turco-brasileiras no caso nuclear iraniano demonstraram a necessidade de se oxigenar os temas candentes contemporâneos. Que a liderança geopolítica capitaneada por EUA, e secundada por europeus (UE) não pode mais agir isoladamente tendo em vista unicamente seus interesses. Que nações emergentes podem e devem protagonizar com ênfase novas tratativas e caminhos menos turvo e mais transparente, onde os interesses conflitantes sejam reconhecidos e debatidos.

No quadro político árabe-muçulmano, Ancara despontou como liderança em importantes linhas que merecem destaque:

Op. Cit. A Alemanha faz parte do Sexteto para o caso nuclear iraniano, e vem seguidamente assumindo fórum de membro permanente do Conselho de Segurança, sem selo por direito, influindo nas votações e utilizando seu imenso poderio econômico a favor das posturas unilaterais de EUA e Reino Unido. Ver casos como da ex- Iugoslávia, Iraque, Irã, Líbia e mais recente, Síria. www.globalresearch.ca/renascimiento-aleman. 10/09/2011. 
Artigo original

Hegemonia - Revista Eletrônica de Relações Internacionais do Centro Universitário Unieuro

ISSN: 1809-1261

UNIEURO, Brasília, número 9, 2012, pp. 68-104.

> Como liderança diplomática e a nível estatal, a Turquia remonta os tempos do otomanismo quando dialoga frente a frente com as grandes potências, e põe a vista sua discordância, os erros cometidos por EUA e União Européia ao não reconhecer a legitimidade iraniana em buscar alternativas energéticas para seu desenvolvimento.

> No terreno social e popular a Turquia se afiança como o novo standar do mundo muçulmano, defensora da autodeterminação dos povos árabes e muçulmanos a escolherem seu próprio caminho, sendo Erdogan carregado em retratos pelas capitais árabes;

> Se tornou a Turquia centro das mais notáveis discussões e deliberações da política pan-islâmica, sobrepujando a Arábia Saudita, e se congraçando com regimes tão próximos e tão distantes como o de Teerã e Riad; assume o papel de ponte, mas uma ponte onde o trafego é monitorado por sua habilidosa geopolítica neo-otomanista, mais autonomista e soberana que o Cairo de Mubarak ou a monarquia saudita;

Também o Brasil, com acentuado destaque nesta celeuma internacional, promoveu distinguidas iniciativas que o credenciam a assumir maiores papéis no cenário árabe-muçulmano. Algumas estão listadas como;

> Como pivô econômico e político latino-americano, e em especial do Mercosul, a liderança brasileira carrega em si o peso do subcontinente sul-americano, que cada vez mais assume contornos próprios na arena política global.

> Pátria de aproximadamente 10 milhões de árabes-descendentes, o Brasil não pode mais deixar a leste as questões candentes que povoam o Oriente Médio, devendo atuar cada vez mais como parceiro construtivo e, sobretudo, alternativa neutra às já conhecidas posturas ocidentais - EUA e União Européia.

> Investir cada vez mais nos acordos procedimentais diplomáticos como ferramentas concertadas em conjunto para solução de 
Artigo original

Hegemonia - Revista Eletrônica de Relações Internacionais do Centro Universitário Unieuro

ISSN: $1809-1261$

UNIEURO, Brasília, número 9, 2012, pp. 68-104.

conflitos, forma habilidosa que o Brasil vem se aperfeiçoando rotineiramente. Neste prisma, não deixar "morrer" o acordo turco-brasileiro que é o instrumento mais avançado a que se chegou no caso nuclear iraniano.

\section{Conclusões}

Num lapso de um ano, três draconianas medidas punitivas foram endereçadas ao Irã pelas potências européias mais EUA. Em 2009, as sanções sobre o comércio e sistema financeiro do país asiático, aprovadas após fortes pressões de Washington, Londres e Bruxelas no Conselho de Segurança; acrescentando ainda as medidas punitivas unilaterais desde 2008 enfeixadas por EUA e União Européia. No marco das eleições gerais iranianas no mesmo ano de 2009, o mundo pode ver as investidas e intervenções na política interna do país por parte das mesmas potências, no financiamento, preparação e alento à "oposição armada". Nas ruas de Teerã, Isfahan, Shiraz, e outras metrópoles iranianas, cenas nunca vistas nos últimos vinte anos de estabilidade desde o ocaso da guerra com o Iraque. Bandas armadas e ondas furiosas de manifestantes atacando instalações públicas, autoridades civis, algumas mesquitas e até o Majilis (parlamento) foram alvos da depredação desses grupos instigados do exterior. ${ }^{32}$

A última dessas medidas punitivas foi a resolução 1929 de que trata o presente texto, que ante o desenvolvimento das negociações encabeçadas por Brasil e Turquia, em positivo avanço, foram sustadas abruptamente. Ora, não se pode chegar a qualquer entendimento com a parte principal - Irã - acuando-a de todos os

Abascal, Ernesto Gomez. Cambios en el Norte de África y Medio Oriente: Hacia donde nos pueden llevar los acontecimientos?. In: www.rebelion.org/noticia/titular-cambios -en-el... 13/09/2011. 
Artigo original

Hegemonia - Revista Eletrônica de Relações Internacionais do Centro Universitário Unieuro

ISSN: 1809-1261

UNIEURO, Brasília, número 9, 2012, pp. 68-104.

lados, com tons ameaçadores e cenas belicistas cotidianas. Diga-se de passagem, durante os meses precedentes a Declaração de Teerã, e durante os trabalhos sistemáticos de Brasil e Turquia, EUA e Reino Unido reforçaram sem paralelo a presença militar no Golfo Pérsico, em frente as costas iranianas. Num gesto de desvelada intimidação fizeram cruzar o Estreito de Ormuz a nave de guerra Abraham Lincolm, porta aviões a propulsão nuclear, ao norte do estreito, bem ao largo do litoral iraniano, quase em suas águas territoriais. A frenética exibição armamentista tem por objetivo demonstrável a intimidação do regime islâmico em primeira linha, mas também visa o malogro das iniciativas diplomáticas em consecução. Dotado de forte espírito de luta, sólido regime político erguido na sangrenta guerra de oito anos contra o Iraque, e uma enorme população, grande parte reservista militar, é quase uma ingenuidade pensar que a República Islâmica se intimidará com estas demonstrações de força.

Resta pois, a esperança diante dos fatos que os atores envoltos no caso nuclear iraniano sejam laboriosos o suficiente para garantirem o desfecho pacífico pela via diplomática. A advertência da escalada militar em torno do Irã vem de todos os lados, e não menos preocupante são as advertências vindas de Moscou e Pequim sobre a desestabilização global que uma ataque unilateral ao Irã poderia causar. E entende-se unilateral por parte de russos e chineses, mesmo uma decisão oriunda das Nações Unidas, instrumentalizada por EUA e União Européia, ao arrepio do direto internacional, tal como expressou a ofensiva sobre a Líbia.

É hora de Brasília e Ancara lançarem mão de seu protagonismo em suas respectivas áreas de influência, para conjuntamente com os esforços de Rússia e China, construírem um novo Quarteto, quinteto ou grupo de trabalho, crível e sério, que resolva de uma vez por todas o caso nuclear iraniano. A disposição de Teerã em cooperar já é suficientemente conhecida, embora hajam forças contrárias aos entendimentos internacionais, forças estas conhecidas por sua oposição colérica ao regime islâmico. No entanto, o cumprimento dos acordos tripartite de maio de 2010, é o mapa do caminho a seguir, pois foi o máximo a que se chegou garantindo a soberania iraniana. 
Artigo original

Hegemonia - Revista Eletrônica de Relações Internacionais do Centro Universitário Unieuro

ISSN: $1809-1261$

UNIEURO, Brasília, número 9, 2012, pp. 68-104.

Uma construção de relevo geopolítico e diplomático concebido por Brasil e Turquia, que pode ser didaticamente estudado e difundido. ${ }^{33}$ É o que revela a experiência.

\section{Referências bibliográficas}

Ali, Tariq. Confronto de Fundamentalismos. São Paulo: Record. 2a edição. 2005.

Amin, Samir. Os Desafios da Mundialização. Aparecida, SP: Idéias e Letras. $1^{\mathrm{a}}$ Ed. 2006.

Chomsky, Noam. Novas e Velhas Ordens Mundiais. São Paulo: Scritta. $1^{\text {a }}$ edição. 1998

Fisk, Robert. Pobre Nação: O Líbano na Segunda Metade do Século XX. São Paulo: Record. 2007

Fromkin, David. Paz e Guerra no Oriente Médio. Rio de Janeiro: Contraponto. $1^{\text {a }}$ Ed. 2008.

Hobsbawn, Eric. Era dos Extremos. Rio de Janeiro: Cia. das Letras. $2^{a}$ Ed. 1999.

Oz, Amós. O Retorno: A volta do povo judeu a Eretz Israel. Emb. de Israel, Brasília, DF. 2001.

Said, Edward. Cartas da Palestina. Petrópolis: Vozes. 2a Ed. 1999.

Sawan, Farid. Al Quds: a Santa. Jerusalém para todos. Emb. da Palestina, Brasília, DF. 2000

Kozirev, Dimitri. Agência de notícias russa Ria Novosti. Brasil e Turquia son ejemplos de Madurez Diplomática. 10/08/2010. Disponível em: www.rianovosti.ru/opiniones/kozirev/brasil-turquia. 


\section{Artigo original}

Hegemonia - Revista Eletrônica de Relações Internacionais do Centro Universitário Unieuro

ISSN: 1809-1261

UNIEURO, Brasília, número 9, 2012, pp. 68-104.

Zizek, Slavoj. Bem Vindo ao Deserto do Real. São Paulo: Boitempo editorial. 2005.

\section{Notas consultadas em sítios da web}

www.rianovosti.ru/sp - Agência de notícias russa Ria Novosti.

www.itamaraty.gov.br - Sítio do Ministério de Relações Exteriores do Brasil.

www.mdci.gov.br - Sítio do Ministério do Desenvolvimento e Comércio Exterior do Brasil.

www.correioweb.com.br - Sítio do Jornal Correio Braziliense, Brasília, DF.

www.ig.org.br - Último Segundo. Agência de Notícias da web. 